\title{
Safety Evaluation of Chicken Satay In Yogyakarta Indonesia Based on Benzo[a]pyrene Content
}

\author{
Khairunissa Irnanda ${ }^{1}$, Argandita Meiftasari ${ }^{1}$, Standie Nagadi ${ }^{1}$, \\ Endang Lukitaningsih ${ }^{2 *}$ \\ ${ }^{1}$ Cancer Chemoprevention Research Center Faculty of Pharmacy, Universitas Gadjah Mada,JalanSekip Utara 555281 \\ (Phone. 02746492662 Fax. 543120) http://ccrc.farmasi.ugm.ac.id \\ ${ }^{2}$ Departement of Pharmaceutical Chemistry, Faculty of Pharmacy, Universitas Gadjah Mada \\ Jalan Sekip utara, Yogyakarta 555281, Indonesia.
}

\begin{abstract}
Chicken satay is one of Indonesian food which is very popular and processed by direct flame over the meat. But, almost every types of food which are prepared by direct flame will produce chemical compounds that contributes to the incidence of cancer. Polycyclic aromatic hydrocarbons (PAH) is a group of compound which can cause cancer and is resulted from the incomplete combustion of fossil fuels or pyrolysis of organic material containing carbon and hydrogen atoms. One PAH compound having mutagenic and highly carcinogenic effect is benzo[a]pyrene which is the highest content found in foods that are burned directly on the flame. This study aims to establish levels of benzo[a]pyrene contained in chicken satay in Yogyakarta, Indonesia and to evaluate how it meets with the maximumbenzo[a]pyrene limit in the burned food based on National Agency of Drug and Food Control which is equal to $5 \mathrm{ppb}(5 \mathrm{mg} / \mathrm{kg})$. Analysis were performed by Gas Chromatography method using helium as carrier gas and CPCB-Sil8 as stationary phase. After the sample was prepared and analysed by GC, it is known that the amount of benzo[a]pyrene in chicken satay found in Yogyakarta are ranging from 2.5 to $393.32 \mathrm{ppb}$. The result are quite high and far above the safety limit determined by National Agency of Drug and Food Control.Therefore, the result of the research needs to be socialized to the public so that people can be more aware about the danger of food they consume.
\end{abstract}

Keywords: chicken satay, benzo[a]pyrene (BaP), policyclic aromatic hidrocarbon (PAH), carsinogen, Yogyakarta

\section{INTRODUCTION}

Grilled food is one of the favorite dish in Indonesia. One of the endemic grilled food in Indonesia is chicken satay, that could be easily found everywhere. Unfortunately, behind its delicious flavour, there is danger hidden in this dishfor body health. Almost every food that cooked on direct flames can cause cancer (Chen and Chen, 2005). One of the cause being responsible for cancer initiation is carcinogen. Carcinogen can cause genetic mutation called initiation process in carcinogenesis prestadium. The abnormal gene which called oncogene could take part in cell cycle regulation and leading to abnormal growth of the cells which usually is ended by dying (Guyton and Hall, 2006). Carcinogen which is commonly found in the environment is polycyclic aromatic hydrocarbons (PAHs) group

Polycyclic aromatic hydrocarbons are formed by the incomplete combustion of organic matterand are thus are generated whenever fossil fuels or vegetation is burned. They are one of several classes of carcinogenic chemicals presented in tobacco smoke. Cooking and food processing at high temperatures have shown to generate various kinds of genotoxic substances or cooking toxicants, including PAHs (Agerstad and Skog, 2005).

*Corresponding author e-mail: lukitaningsih_end@ugm.ac.id 
Grilling (broiling) meat, fish, or another foods with intense heat over a direct flame results in fat dripping on the hot fire and yields flames containing a number of PAHs (Agerstad and Skog, 2005) that then adhere to the surface of the food.The more intense the heat is, the more PAHs formed (Larsson, 1986). OnePAHs compound having mutagenic effect is benzo[a]pyrene (International Agency Research on Cancer, 1983). Highest concentrations of benzo[a]pyrene have been found in food cooked over open flames (Panalaks, 1976). Therefore, cooking chicken satay in direct flame and high temperature could increased the risk to people consuming it.

National Agency of Drug and Food Control of Indonesia has declared a policy that the limit the concentration of benzo[a]pyrene in grilled food, with the maximum value of $5 \mathrm{ppb}$ that is equal to $5 \mu \mathrm{g} / \mathrm{kg}$ (National Agency of Drug and Food Control, 2009). The aim of this study is to analyze benzo[a]pyrene in chicken satay in some areas in Yogyakarta. Hopefully, the study will provide an information as reference for the safety of consuming chicken satay.

\section{MATERIALS AND METHODS}

\section{Standards and Reagents}

Benzo[a]pyrene (B[a]P) standard, acetone p.a. (E.Merck), n-hexane p.a. (E.Merck), sodium sulfate anhydrate (E. Merck), alumina (E.Merck), and aquabidest were purchased from LPPT UGM.

\section{Samples}

Chicken satay samples were purchased from sellers in three different places in Yogyakarta, Indonesia such as Malioboro, Tugu, and Condong Catur at the same time, with the weight of 60 grams each. The samples were blended using blender (National, Indonesia) and kept at $20^{\circ} \mathrm{C}$ prior to extraction and analysis.

\section{Extraction and Clean-up of Samples}

Validation method of sample preparation was done according to the method described by Lukitaningsih and Sudarmanto (2010). Each blended sample $( \pm 60 \mathrm{~g})$ was homogenized for $3 \times 24$ hours in $500 \mathrm{ml}$ hexane-acetone $(1: 1)$ and put in a shaker. The extract was then filtered and sodium sulfate anhydrate was added to the residue. Extract was evaporated until there is only $5 \mathrm{ml}$ left and was cleaned up with column chromatography. Activated alumina was used as stationary phase and elution was done with hexane-acetone followed by hexane as the mobile phases. Each solvent was evaporated and $1 \mathrm{ml}$ residue was dissolved in hexane yielding a total volume of $5 \mathrm{ml}$.

\section{Benzo[a]pyrene Standard Determination by Capillary Column Gas Chromatography}

Benzo[a]pyrene standard analysis was carried out using a GC apparatus (Shimadzu GC-2010) equipped with split type of injector port AOC-INJ with 10:1 split ratio, CP-Sil8-CB column $(0.25 \mathrm{~mm} \times 30 \mathrm{~m} \times 0.25 \mu \mathrm{m})$, FID1 detector channel. Oven temperature setted $180^{\circ} \mathrm{C}$, injection column temperature was set to $315^{\circ} \mathrm{C}$, and Shimadzu VP class was used to operate $\mathrm{GC}$ and to analyze data.Helium at flow rate $10 \mathrm{ml} / \mathrm{min}$ was used as carrier gas. Separation was performed under isocratic condition. Each sample solution $(2 \mu \mathrm{l})$ was injected to the injector port into the GC system. The quantification of $\mathrm{B}[\mathrm{a}] \mathrm{P}$ was performed by the use of an external calibration curve method.

\section{RESULTS AND DISCUSSION}

Identification of $\mathrm{B}[\mathrm{a}] \mathrm{P}$ in chicken satay was obtained on the basis of comparison of capilary colum $\mathrm{GC}$ retention times of $\mathrm{B}[\mathrm{a}] \mathrm{P}$ standard. Typical capillary column GC of B[a]P are presented in Fig 1. The calibration curve, linear equation, coefficient of regression $\left(\mathrm{R}^{2}\right)$ and limits of detection and quantification (LOD\&LOQ) obtained using the signal-tonoise ratio as $\mathrm{S} / \mathrm{N}=10$, respectively (Lukitaningsih and Sudarmanto, 2010) for PAHs quantification are presented in Table I. The limitsof detection and quantificatin (LOD\&LOQ) were $119.8 \pm 3.9 \mathrm{ng} / \mathrm{peak}$ and 399.3 \pm 8.7 ng/peak. Table II shows the determination of $\mathrm{B}[\mathrm{a}] \mathrm{P}$ in chicken satay by column capillary GC The results showed that $\mathrm{B}[\mathrm{a}] \mathrm{P}$ was detected in all samples in the range 2.5 ppb-393.32 ppb. The minimum concentration of $\mathrm{B}[\mathrm{a}] \mathrm{P}(2.5 \mathrm{ppb})$ was detected in chicken satay from Tugu, and the maximum concentration (393.32 ppb) was detected in chicken satay from Condong Catur. 
Chromatogram Cairan C:IGCsolution DatalProjectl VFIDICairan Kode 8707 Benpyr (Std Bepyr) .ged - Channel 1

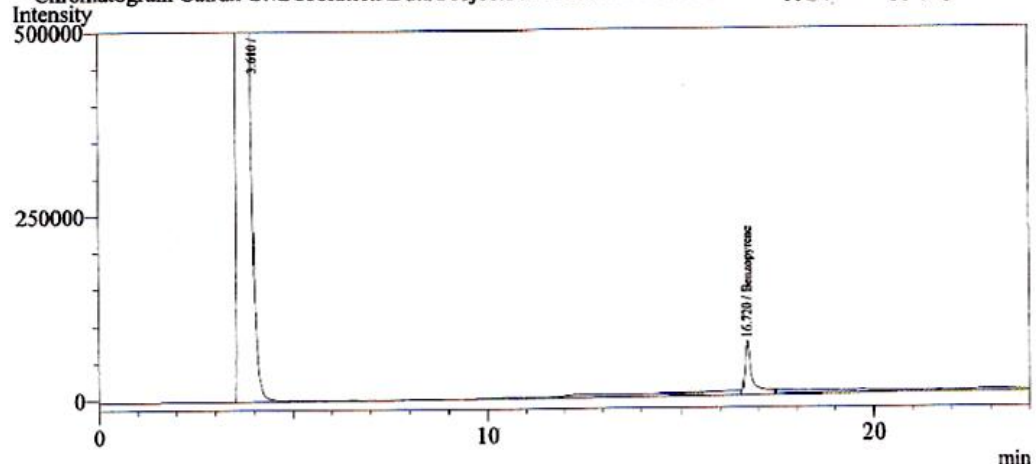

(A)

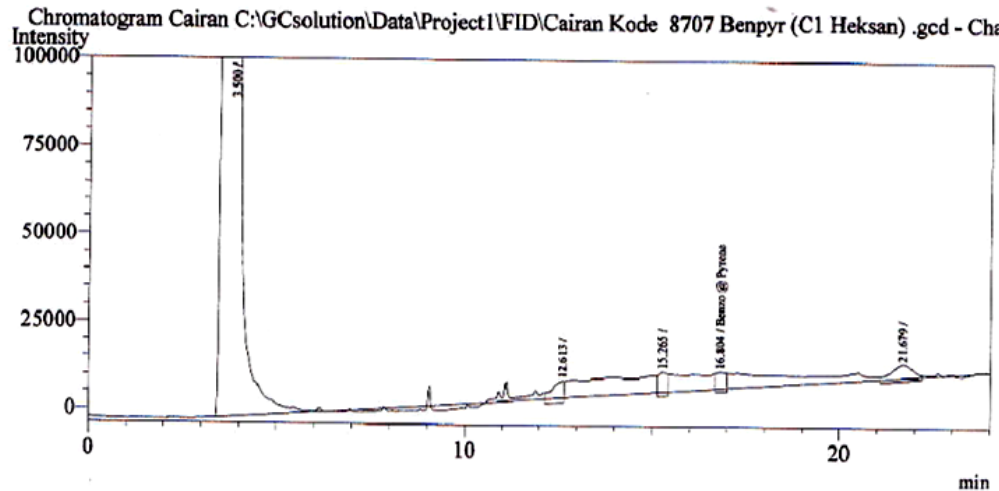

(B)

Chromatogram Cairan C:IGCsolution DatalProjectIVID|Cairan Kode 8707 Benpyr (No Label) .gcd - Channel 1 Intensity

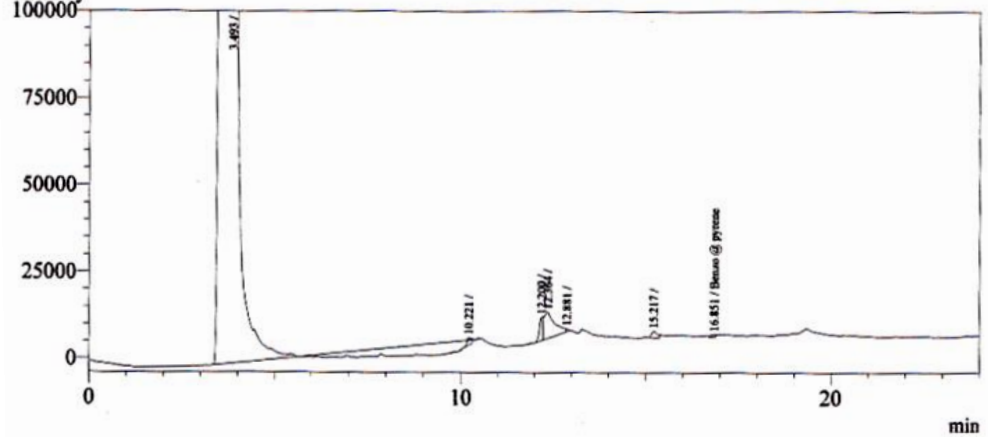

(C)

Zhromatogram Cairan C:IGCsolution DatalProjectIFIDICairan Kode 8707 Benpyr (C2 Heksan-Aceton) .gcd - Channe Intensity

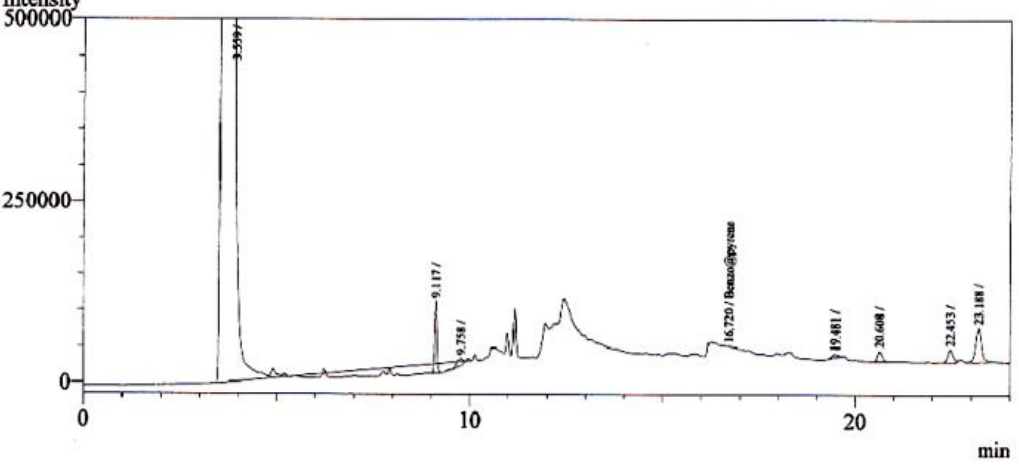

(D)

Figure I. Typical Capillary Column Gas Chromatography : (a) standard, (b) \& (c) hexane fraction of sample from Condong Catur, and (d) hexane-acetone fraction of sample from Condongcatur 
Table I. Limit of detection and quantification (LOD \& LOQ) obtained for quantification of PAHs

\begin{tabular}{|c|c|c|c|c|}
\hline No & Standards & \multicolumn{2}{|c|}{ LOD (ng/peak) } & LOQ (ng/peak) \\
\hline I & Pirene & \multicolumn{2}{|c|}{$22,9 \pm 0,3$} & $76,3 \pm 4,6$ \\
\hline 2 & Benzo[a]antrasene & \multicolumn{2}{|c|}{$111,9 \pm 1,2$} & $373,1 \pm 0,8$ \\
\hline 3 & Benzo[K]antrasene & \multicolumn{2}{|c|}{$139,0 \pm 2,8$} & $463,3 \pm 2,8$ \\
\hline 4 & Benzo[a]pyrene & \multicolumn{2}{|c|}{$119,8 \pm 3,9$} & $399,3 \pm 8,7$ \\
\hline \multicolumn{5}{|c|}{ Table II. Benzo[a]pyrene concentration of chicken satay samples } \\
\hline & Sample & $\begin{array}{l}\text { Area Under } \\
\text { Curve(AUC) }\end{array}$ & $\begin{array}{c}\mathrm{B}[\mathrm{a}] \mathrm{P} \\
\text { concentration } \\
\text { result }(\mathrm{ppm})\end{array}$ & $\begin{array}{c}\mathrm{B}[\mathrm{a}] \mathrm{P} \\
\text { concentration in } \\
\text { sample (ppb) }\end{array}$ \\
\hline & Standar Benzo[a]piren & 922501 & 39.4 & - \\
\hline & $\mathrm{Cl}$ - Heksan & 110540 & 4.72 & 393.32 \\
\hline & C2 - Heksan & 6478 & 0.28 & 23.33 \\
\hline & C2 - Heksan-aseton & 3407 & 0.15 & 12.499 \\
\hline & MI - Heksan & 77606 & 3.31 & 275.847 \\
\hline & M2 - Heksan & 2510 & 0.11 & 9.167 \\
\hline & M2 - Heksan Aseton & 33113 & 1.41 & 117.506 \\
\hline & TI - Heksan & 668 & 0.03 & 2.5 \\
\hline & T2 - Heksan & 2461 & 0.11 & 9.166 \\
\hline & T2 - Heksan-aseton & 4649 & 0.2 & 16.666 \\
\hline
\end{tabular}

However, the average concentration of $\mathrm{B}[\mathrm{a}] \mathrm{P}$ for all fraction showed that chicken satay from Condongcatur contained the highest one (143.05 ppb) and chicken satay from Tugu was the lowest ones $(9.44 \mathrm{ppb})$.And in this group, higher concentration of $\mathrm{B}[\mathrm{a}] \mathrm{P}$ could be due to horizontal source of heat of heat as well, that could not prevent the dropping of the fat from meat into the flame (Farhadian et al., 2010).

From the analysis, it shows a lot of various result, because of the marinated chicken satay could affect $\mathrm{B}[\mathrm{a}] \mathrm{P}$ concentration in chicken satay. In general, this result of $\mathrm{B}[\mathrm{a}] \mathrm{P}$ concentration is higher than policy regulated by BPOM which state that maxmum concentration of $\mathrm{B}[\mathrm{a}] \mathrm{P}$ in the foods is no more than $5 \mathrm{ppb}$ $(5 \mu \mathrm{g} / \mathrm{kg})$. Therefore, this result shows that chicken satay from Yogyakarta contains high $\mathrm{B}[\mathrm{a}] \mathrm{P}$ and over the safety maximum concentration that allowed by National Agency of Drug and Food Control.

Benzo[a]pyrene compound which is contained in food is very dangerous for human health, because in human body this compound will be metabolized into epoxide metabolite (7,8-diol-9,10-epoxide benzo[a]pyrene). This metabolite will interact with $\mathrm{N}$-amino guanin and forms covalent binding or interact with phosphate group from nucleic acid, changes the DNA and RNA structure resulting in abrogation of protein synthesis. If human body could not giving a feedback to turned it over to normal state, cell mutagenesis will be occur and it can cause cancer (Graslund et al., 2008).

Because $\mathrm{B}[\mathrm{a}] \mathrm{P}$ contains in chicken satay was very dangerous for health, the consumption of chicken satay have to be limited and combined with vegetables which rich in flavonoid and antioxidant substances. Hopefully, it could prevent the oxidation process in human body and inhibit the carcinogenesis process.

The authors are now carrying out a study on the influence of ingredients used to marinate chicken satay. Some ingredients might be responsible for generating high concentration of $\mathrm{B}$ [a]P (Farhadian, et al., 2011). It is known that recoating with sauces can often result in burned meat surface (Agerstad and Skog, 2005). Fat content of the sample is also an important factor for $\mathrm{B}[\mathrm{a}] \mathrm{P}$ formation in grilled meat (Fretheim, 1983).

\section{ACKNOWLEDGEMENT}

We acknowledge Directorate General of Higher Education, Ministry of Education and Culture, Republic of Indonesia who has funded this research in 2011.

\section{REFERENCES}

Agerstad, M.J. and Skog, K., 2005, Review Genotoxicity of Heat-Processed Foods, Mutation Research, 574, I56172.

Chen, J. and Chen, S., 2005, Removal of Polycyclic Aromatic Hydrocarbons by Low Density Polyethylene from Liquid Model and Roasted Meat, Food Chemistry, 90, 46I-469. 
Farhadian A., Jinap, S., Abas, F. and Sakar, Z.I., 2010, Determination of Polycyclic Hydrocarbons in Grilled Meat, Food Control, 2 I (5), 606-6I 0.

Farhadian, A., Jinap, S., Hanifah, H.N. and Zaidul, I.S., 20II, Effects of Meat Preheating and Wrapping on the Levels of Polycyclic Aromatic Hydrocarbons in Charcoal-Grilled Meat, Food Chemistry, I 24(I), I4I-I 46.

Fretheim, K., 1983, Polycyclic Aromatic Hydrocarbons in Grilled Meat Products: A review, Food Chemistry, 10, 129-139.

Guyton, A.C. and Hall, J.E., 2006, Textbook of Medical Physiology, I I ${ }^{\text {th }}$ edition, Pennsylvania, Elsevier Inc.

Graslund, S., Sagemak, J., Berglund, H, Dahlgren, L.G., Flores, A. and Hammarstrom, M., 2008, The Use of Systemic N- and C-terminal Deletions to Promote Production and Structural Studies of Recombinant Protein, Protein Expression and Purification, 58(2), 2I0-22I.

International Agency Research on Cancer, 1983. Monographs on the Evaluation of Carcinogenic Risk of Chemicals to
Humans, Polynuclear Aromatic Compounds. Part 1: Chemical environmental and experimental data, Lyon, International Agency Research on Cancer (IARC).

Larsson, B.K., 1986, Polycyclic aromatic hydrocarbons in swedish foods. Aspects on analysis, occurrence and intake, Doctoral thesis, Swedish University of Agricultural Sciences.

National Agency of Drug and Food Control, 2009, Penetapan Batas Maksimum Cemaran Mikroba dan Kimia dalam Makanan, Jakarta.

Lukitaningsih, E. and Sudarmanto, B.S.A., 2010, Bioakumulasi Senyawa Poli-aromatik Hidrokarbon dalam Plankton, Ganggang dan Ikan di Perairan Laut Selatan Jogjakarta, Majalah Farmasi Indonesia, 2 I (I), I8-26.

Panalaks, T., 1976, Determination and Identification of Polycyclic Aromatic Hydrocarbons in Smoked and Charcoal-broiled Food Products by High Pressure Liquid Chromatography and Gas Chromatography, J. Environ. Sci. Health B., I I (4), 299-3 I5. 